Canadian Journal of Family and Youth, 5(1), 2013, pp 1-37

ISSN 1718-9748 (c) University of Alberta

http://ejournals.library.ualberta.ca/index/php/cjfy

\title{
The Evangelical Sexual Marketplace: An Ethnographic Analysis of the Exchange and Conversion of Erotic Capital in an Evangelical Church
}

\author{
Robin D. Willey
}

\begin{abstract}
Since the development of the early church, sexual ethics and the regulation of heterosexual relationships have been integral parts of Christian religious practice. Evangelical Christian communities are no exception to this pattern of regulation. In particular, this article makes three key arguments regarding Evangelical sexual practices. First, heterosexual relationships and marriage have become one of the most important (if not the most important) aspects of Evangelical religious and social practice, surmounting both Baptism and the Eucharist. Second, those in the Evangelical sub-culture tend to find several qualities more or less attractive in a potential mate, some of which differ from those outside the sub-culture. Finally, within many Evangelical churches a defined social space - a sexual marketplace - exists where individual agents exchange and convert this commodity, among others, to attract potential marital partners. The author derives these conclusions from the ethnographic observations and interviews he conducted while attending an urban Canadian Pentecostal Church in 2009 and 2010.
\end{abstract}

\section{Introduction}

"As much as I try to convince myself otherwise, I feel as though I go to church to meet someone first and for God second. I hate this." Although I suspected that abstinence was a valued commodity within Evangelical circles when I started this project,

Robin Willey is finishing his PhD under the supervision of Professor Stephen Kent in the Department of Sociology, University of Alberta. His Master's thesis focused on the value of sexual abstinence in this Evangelical context. Willey's current research interests focus on conservative Christian involvement in Canadian politics. He investigates the intersection between neoconservative political strategy and Christian nationalism in Canada - an intersection otherwise known as theoconservatism. In particular, he is interested in the implications of theoconservatism on government policy related to gender and sexuality. In addition, Mr. Willey has completed some work refining Bordieusian theory's ability to draw theoretical and historical connections between religion and madness through the concept of liminality. 
this quote from a local Pentecostal online confessional ${ }^{1}$ was the first piece of data to confirm that a place existed within the church community to exchange this commodity. Not only does this quote affirm the existence of this "sexual marketplace," but it also reveals some of the discomfort Evangelicals feel about its existence.

While conducting research at Grace Pentecostal, I discovered three dominant and related themes of analysis. ${ }^{2}$ The first of these themes was the importance of heterosexual marriage and relationships at Grace. Discourses surrounding marriage and family were prevalent in virtually every church group and event I visited. The second of these themes was that Evangelical young adults employed several key forms of erotic capital (a concept I explore in more detail later in this article) to attract life partners. Finally, the third theme I derived from my work at Grace was that a defined sexual marketplace existed within the community where certain attributes have greater value.

In this article, I first summarize the theoretical perspective used in this analysis. I then briefly outline the method used to attain the data that I produced. Third, I reveal the importance of heterosexual marriage and relationships to those involved in my project. Then I describe the qualities that the participants in my project consider attractive and important in a mate. In other words, I examine what the members of Grace considered erotic capital, focusing on the three different types that became relevant in this study: worldly, Christian, and virgin. I then reveal the evidence for a sexual marketplace within Grace Pentecostal. I describe this evidence through the "sexual fields framework". Thus, I provide evidence for both "the site" and "the field" (Green, 2008, p. 28). Finally,

\footnotetext{
${ }^{1}$ I have suppressed the specifics of this citation to preserve the anonymity of my participants.

${ }^{2}$ I preserved anonymity and confidentiality by using pseudonyms for both informants and the church itself. In addition, for the five interviews with the congregants, I suppressed all data related to age and occupation to preserve anonymity. In addition to these items for the pastors, I suppressed gender.
} 
through Bourdieu's concept of the "demon" I describe the implications of this marketplace on youth and women. ${ }^{3}$

\section{Literature Review}

In her ethnography of American young adults, sociologist, Amy C. Wilkins considered abstinence to be an identity movement. She stated that we should understand abstinence as more of a "style" rather than a behavior. Abstinence provides the practitioner with an identity marker that symbolically sets one apart from the rest of society. That said, Wilkins argued that youth do not abstain solely because they are "good Christians" (Wilkins, 2008, p. 120). Most notably, Wilkins believed that these youth used abstinence as a way to navigate particular gender-based expectations. First, abstinence provided a mechanism for male practitioners to account for failure in the "normal" heterosexual arena; it became a technique young men use to deal with "rejection, heterosexual disinterest, and ... vulnerability" (Wilkins, 2008. p. 125). Abstinent men emphasized that abstinence was a "choice" and that they are engaged in a constant struggle against temptation. Wilkins noted that these men often expressed this "struggle" collectively in what she calls "temptation talk." This "talk" is what transforms “heterosexual non-participation” into "abstinence” (Wilkins, 2008, p. 129).

For women, according to Wilkins, abstinence is linked to purity, which in turn, is enforced through "shame.” (Wilkins, 2008, p. 137). "Shame,” stated Wilkins, "teaches

\footnotetext{
${ }^{3}$ This article is a reduced version of my Master's thesis titled "Discovering the Evangelical Sexual Marketplace: An Ethnographic Analysis of the Development, Exchange, and Conversion of Erotic Capital in an Evangelical Church." A version of which was presented at the "Pacific Northwest AAR/SBL and ASOR Annual Meeting" in Spokane, Washington on May 14, 2011. In this study, I utilized archives from the Stephen A. Kent Alternative Religions Collection housed at the University of Alberta Library. I would like to thank Dr. Kent, Terra Manca, Jeffery Andrews, and Timothy Dunfield for assistance editing and providing me with the guidance and advice necessary to complete this project. Moreover, I would like to thank Silvio Mantello, Ann Normand, and Andrea Willey for their editorial efforts.
} 
Willey

individual women to scan their inner selves to make sure they line up with social expectations" (Wilkins, 2008, p. 138). Therefore, shame not only forced women to avoid premarital sex; it drove them to fear any tarnishing of their feminine purity.

Consequently, as Wilkins observed in her study, what begins as sexual abstinence can transform easily into "romantic abstinence," the complete withdrawal from any form of heterosexual intimacy until marriage (Wilkins, 2008, p. 138).

Additional material attempts to look into gender constructions and identities within heterosexual Evangelical relationships. For the most part, these works determine that gender roles within Evangelicalism are founded on essentialism and patriarchy legitimized through biblical texts and popular psychology (Pevey, et al., 1996;

Bartkowski, 2001; Gallagher, 2003; Gallagher \& Wood, 2005). Many Evangelical women, however, do not conform exactly to the ideals of femininity as set out in dominant Evangelically-defined gender roles. First, contemporary Evangelical women are just as likely to participate in the workplace (Gallagher, 2003, p. 134). Second, they also have learned ways of working around ideas of hierarchy and submission (Pevey, et al., 1996, p. 189).

While some feminists have argued that sexual abstinence and/or purity can provide women a powerful way to escape mainstream sexual discourses (for example Abbott, 1999, p. 440), most have been critical of the movement. Feminist author and founder of feministing.org, Jessica Valenti, argued that men and male-led institutions always have defined and given value to purity and virginity (Valenti, 2009, p. 22). Valenti argues that, for women, virginity has become a replacement for morality. Virgin 


\section{Evangelical Sexual Marketplace}

women can act as ignorant and immoral as they want as long as they remain chaste.

Thus, purity relies on a passive definition of womanhood (Valenti, 2009, p. 24).

That said, the rhetoric of the purity movement implies that purity takes strength and action (Valenti, 2009, p. 25). And to some extent, as mentioned earlier, purity does provide some temporary space within the tight conservative gender roles and scripts provided to them. Future rewards, however, of traditional Christian marriage legitimize this space, where the two parties reinstate dominant heterosexual discourses (Wilkins, 2008, pp. 133, 143). Therefore, despite the rhetoric of the purity movement, which asserts that purity requires strength and integrity, a woman's worth is still contingent on her "virginity" (Valenti, 2009, p. 25).

In contrast, discourse surrounding male abstinence makes virginity sound like a battle - a toil of inner virtue and vice (Wilkins, 2008, p. 124). ${ }^{4}$ For men, purity is a choice. Through this choice rhetoric, they are able to maintain a level of autonomy and authority to which women are not privileged (Wilkins, 2008, p. 124). Thus, purity for men is more about "saving" other men's daughters from premarital sex than "saving" one's own "virginity" for the marital bed. ${ }^{5}$

\section{Theoretical Perspective}

\section{Pierre Bourdieu: Key concepts and definitions}

Social space (i.e. society) for Pierre Bourdieu (1930-2002) was multidimensional, composed of any number of "fields," which intersect and overlap in different ways and in different spaces. Simply put, a field is an arena for competition, a place where agents and

\footnotetext{
${ }^{4}$ Society has feminized the terms "virgin," "virginity," or "purity" to such an extent that I struggle to use it when I speak of men. I have managed, however, to push past this rhetorical struggle for the sake of clarity. ${ }^{5}$ For an extensive literature review on the subject of Evangelicalism and sexuality see Willey [2010A].
} 
Willey

institutions compete for various forms of legitimate capital (Bourdieu 1996, p. 40).

Furthermore, these fields are homogenous insofar as they function by similar logic (Rey, 2004, p. 332). For every form of capital, a related field exists where agents and institutions jockey for position and the accumulation, consumption, and/or production of the associated form of capital. The forms of capital acquired from these fields then prescribe one a position in the "meta-field of power" (Rey, 2007, p. 45). ${ }^{6}$

Habitus is what provides agents with the knowledge and the tools to participate in this struggle for capital—providing individuals with a "feel for the game" (Bourdieu, 1998, p. 25). In other words, it determines their "practice," which is the focus of much of Bourdieu's theoretical work (see Bourdieu 1977; Bourdieu \& Wacquant 1992). In Practical Reason, Bourdieu describes habitus as:

generative principles of distinct and distinctive practices - what the worker eats, and especially the way he eats it, his political opinions and the way he expresses them are systematically different from the industrial owner's corresponding activities. But habitus are also classificatory schemes, principles of classification, principles of vision and division, different tastes (Bourdieu 1998: 8).

The habitus is what links agents to the material world, as it is fostered by one's material conditions of existence. From here, through a person's tastes and habits, the habitus renders various fields of the social world meaningful, and vicariously the various fields of the social world shape the habitus of individual agents (Bourdieu 1998, p. 8). Therefore, the habitus positions agents within a field, which in turn provides the agent with a certain amount of capital relative to that position. For example, one's habitus determines an

\footnotetext{
${ }^{6}$ The field of power is where agents compete over the control of the state and its "statist capital granting power of the different species of capital and their reproduction" (Bourdieu 1998, p. 42 [emphasis added]). For example, statist capital, gained through the field of power, can influence the ability of the educational institution to grant degrees and thus influence the educational field and its ability to produce (and reproduce) educational capital. The field of power, therefore, is the primary location for class struggle and domination.
} 


\section{Evangelical Sexual Marketplace}

agent's position within the religious field, which gives the agent access to a certain amount of religious capital.

Bourdieu's understanding of capital began with a traditionally Marxist understanding. Essentially, Bourdieu and Marx understood capital as accumulated labour that enables social agents to "appropriate social energy in the form of reified or living labor." Capital, for Bourdieu, gives the social world "inertia" and is what changes this world from being a simple game of chance to one altered by "accumulation," “hereditary,” and “acquired properties" (Bourdieu 1986). That said, Bourdieu greatly increased the efficacy of this Marxist concept by extending beyond its strictly materialist connotations (Rey, 2007, p. 52).

Bourdieu divided capital into three "fundamental guises" from which all forms of capital take their form. In short, economic capital is capital in the Marxist sense. People who have a greater degree of control over the means of production have greater amounts of economic capital. Cultural capital exists in the form of a person's tastes, values, education, and credentials of all sorts. Individuals derive social capital from the personal, intimate, and informal networks and bonds we form with others (Bourdieu, 1986;

Putnam, 2000, p. 20; Wuthnow, 2000). While cultural capital has to do with what one knows, social capital tends to depend on who one knows.

\section{Religious Capital}

Credentials are an important aspect of cultural capital. The most important credential for an Evangelical Christian is conversion, most notably adult conversion, here 
one supposedly becomes reborn by the Holy Spirit (Fowler, et al., 2004, p. 15). ${ }^{7}$

Theologically, this experience marks the moment where one is saved; where God's grace assures one's salvation. More importantly, however, is the story that comes with this experience of conversion-visions and relief from depravity and/or sinfulness. As well, realizations of previous wrongdoings are common themes of these stories. Often these stories develop from what one journalist termed "The culture of personal crisis" that “defines so many Evangelical communities” (Blumenthal, 2009).

The better the conversion story one can tell (involving the utmost amount of personal trauma), the greater amounts of cultural capital one can accumulate as a result. For instance, often people construct conversion accounts in ways that match the requirements and terminology that is appropriate to their given group. In addition, often agents alter their accounts over time to fit their situations - to fit any changes in their social positions (Snow \& Machalek, 1984, p, 176). If a community comes to consider financial turmoil to be a paramount issue in society, then parishioners may overemphasize their financial situations at the time they converted. Along with other ritual events such as baptism and confirmation, conversion acts as a "prerequisite" for further action within Evangelical circles.

Within Evangelical Christianity (and all other forms of religion for that matter), we can see the existence of another form of capital: religious capital (see Bourdieu, 1987; 1991). Despite being a form of cultural capital, religious capital is specific to religious communities. In Evangelicalism, knowledge of rituals and texts, especially the Bible, is

\footnotetext{
${ }^{7}$ For many Evangelicals, Pentecostals in particular, this rebirth symbolizes a second baptism by "fire." This second baptism follows from the events of Pentecost in the Book of Acts. Here the author described when Christ's disciples first experienced the Holy Spirit. In addition, through the "gifts" provided by the Spirit the disciples were able to convince thousands to convert and be baptized. This event provided the foundation for the early Church (Conkin, 1997, pp. 288-289).
} 
very important. Being able to interpret biblical texts in a way that legitimizes and reproduces the community's perspective can help an individual to rise within the church. These people become the core of the Evangelical priestly class, and knowledge of the Bible can help a person rise within it (Bourdieu, 1987, p. 127). ${ }^{8}$

Evangelicals must learn the proper ways to express their religious and spiritual capital. Spiritual capital has to do with the methods that religious agents use to display their relationship with what they consider to be the divine. It is highly fluid and exists across religious lines, albeit in different ways (Verter, 2003). This form of capital is more easily traded than religious capital, because it is not confined to one specific religious denomination's texts, rituals, and dogmas. Rather, spiritual capital is what allows religious persons to better use religious capital. No matter what form a deity or supernatural phenomenon may take, individual believers must attempt to communicate with it in some way. From my understanding, this notion is spiritual capital.

\section{Erotic Capital}

Another example of cultural capital that is particularly important to Evangelical Christians and this article is compliance to sexual norms. Just like many modern social groups, Evangelicals are sex-obsessed. As such, it is important to understand the ability of one's sexual status to evoke erotic desire in others. From this perspective, one's status as an abstainer acts as a form of "erotic" or "sexual capital" (Martin \& George, 2006;

\footnotetext{
${ }^{8}$ When defining religious capital, Bourdieu argued that Weber's concept of charisma "must be understood in relational terms" (Engler, 2003, p. 446). Through this process, Bourdieu conceptualized religions as having two primary forces: namely the "priest" and the "prophet" (Bourdieu, 1987; 1991). The priest represents the forces of orthodoxy that vie for control of "religious capital" against the prophet and the forces of heterodoxy. Thus for Bourdieu, Weber's concept of the "routinization of charismatic authority" represents the "consolidation of control over religious capital, as prophet becomes priest." Furthermore, Bourdieu emphasized that a charismatic prophet requires specific material conditions in order for his heresy to gain followers (Bourdieu, 1987, p. 130).
} 
Green, 2008). In short, erotic capital is "the quality and quantity of attributes that an individual possesses, which elicit an erotic response in another" (Green, 2008, p. 29). In other words, erotic capital is what people consider "sexy."

Like all other forms of capital, the erotic variety links directly to one's habitus; what one considers sexy is explicitly related to one's objective social history (Green, 2008, p. 30). Unlike some other forms of capital, however, the field of where one can exchange erotic capital for other forms often is linked to a physical site, such as a bar, or in this case a church (Green, 2008, p. 28). That said, the goal for Evangelicals is not just to "elicit an erotic response in another," but rather, it is to induce an erotic/emotional response that could potentially lead to marriage - in addition to sex. Nonetheless, the addition of marriage only changes what Evangelicals consider attractive and does little to change how they use erotic capital. ${ }^{9}$

\section{Methods}

My work at Grace would be more appropriately described as what Loïc Wacquant calls "observant participation" rather than participant observation (Wacquant, 2004, p. 5). ${ }^{10}$ By this comment, I do not mean that the church swept me away in some religious fervor. There were countless times that I found myself actively debating with the members of the congregation in discussion groups, conversing openly with individuals, and contemplating the exact purpose of a sociologist in this context. Moreover,

\footnotetext{
${ }^{9} \mathrm{I}$ had thoughts of creating a form of capital at this point, such as romantic or courting capital. I feel, however, this change would take away from the role that sexual politics play in abstinence practices and discourses. Thus, I will continue to use Green's term - erotic capital.

${ }^{10}$ I gained ethics approval as part of the requirements for the class for which this study took place. Prior to commencing the research project, I provided a research script describing my project to one of the church leaders and asked for permission to attend church services and functions. I required that all participants sign detailed consent forms. Furthermore, the potential risk of harm for those involved was minimal and met the guidelines set out in the Tri-Council Policy Statement on Ethics.
} 


\section{Evangelical Sexual Marketplace}

considering that contemplation was very much the goal of great portions of the young adult services, this activity was far closer to participation than observation.

By the time I had terminated observation, I had attained seven interviews: five congregants and two pastors. I kept detailed fieldnotes of all of my research activity. I took these notes from a reflexive perspective to preserve my awareness of the constructed nature of my observations (Bloor \& Wood, 2006, p. 145). This process enabled me to bracket some of my own perceptions and biases, and better understand my own position within the fields relevant to the community. In this way, reflexivity helped to increase the level of objectivity and validity in my observations.

At the completion of the observation period, I transferred all of the interviews and field notes into NVIVO 7 where I analyzed and coded them for any themes, patterns, discourses, and/or ideologies that were prominent. In this process, I particularly focused on codes involving abstinence and sexuality.

That said, while the design of my project encouraged depth and quality of data, it also created a number of limitations. Several notable limitations exist about this project. First, as with all ethnographies, the problem of replicability remains. To the best of my abilities, I tried to offset this deficiency through triangulation. I completed this process by using multiple methods: participant observation, interviews, and thematic analysis of internal and external resources. Nonetheless, I cannot guarantee that another ethnographer could return to Grace and draw the same conclusions.

Second, it took far longer to gain access to the group than I expected. Gaining the rapport necessary to ask for interviews related to a sensitive topic, such as sexuality and religious belief, proved incredibly time consuming. Moreover, because I had to complete 
Willey

this project as part of my Master's requirements and thus had to finish it by a certain date, I was unable to extend my project any longer to compensate for this issue. I feel that with additional interviews and observations, I could have provided a greater depth of analysis.

Finally, my project was limited to a single site - a single Evangelical church. This situation greatly limits the conclusions I can draw. While I can state that Evangelical churches generally have similar structures and reproduce similar discourses (Reimer, 2003, p. 118), I obviously cannot guarantee that one will find a defined sexual marketplace in every Evangelical church one encounters.

\section{Results and Discussion}

Understanding the Importance of Heterosexual Marriage and Relationships

Through the duration of this project, I never doubted the importance of heterosexual marriage and relationships to my participants. In fact, I would argue that Evangelicals have elevated marriage to one of the most paramount (if not the most paramount) rituals in Christianity, surpassing both the Eucharist and baptism. It is so important, that, as one of my participants described to me, even homosexual Evangelicals (such as Brian Pengelly who describes himself as "a Gay, Evangelical Christian Youth Pastor, who is married to a Lesbian" [Pengelly, 2010]) marry a member of the opposite sex. Next to religious status, marital status is the primary means by which (my participants at least) defined themselves: one is either married, dating, single, or what Pastor Alex termed, "desperately single.” 
The inclusion of this category by Pastor Alex reinforces the importance of heterosexual relationships for Evangelical young adults. These individuals desperately seek the validation of a partner, their community, and God. Alice, a married female participant, admitted that at one time she feared that she would never meet a suitable mate. Matt, a single male participant, lamented his struggles to find a mate and continues to wait for fate, or "the right social circumstances," to bring this person to him.

Furthermore, Matt and several other participants intricately connected the process of finding a mate with divine design and God's will. Allen, a married male, stated that he just had to wait for "God's timing," when it came to meeting his life partner. Pastor Jordan suggested that it was a real "God kind of thing" that brought her/him to her/his partner. ${ }^{11}$ Pastor Jordan also believed that young persons needed to place more trust in God for meeting a mate.

Several of the male participants firmly held that the sole purpose of dating was marriage. In one instance, Allen said:

My view of dating has always been, well it can be for fun and hanging out and everything. Dating for me, its primary function is to find a life mate, right? . . . And until you're ready for that I don't see it as serving any purpose. You know, fourteen-year-olds going out and dating, I just wouldn't agree with. There is no point in that.

Stan, a single male, reiterated this point. He acknowledged that he completely pushed off the idea of dating until he had resolved his "ambition." In addition, Pastor Alex suggested that one should consider another's future husband or wife when dating, and

\footnotetext{
${ }^{11}$ In order to make the most of my data while preserving the anonymity of my participants, I needed to suppress pseudonyms and gender in some instances.
} 
even suggested that young men should vet a woman's father prior to initiating any sort of relationship (a process very similar to that supported by the purity ball movement). ${ }^{12}$

Furthermore, both Stan and Allen believed that there was a proper time for marriage and both were fully committed to wait until this time arrived; neither worried about struggling to find a mate. In fact, Allen revealed quite the opposite:

My criteria? I have pretty high standards. I probably couldn't be with someone ... who had been with someone.... But I felt that I was a pretty good catch, especially compared to so many other people out there.

Both Stan and Allen revealed a great deal of confidence, even nonchalance, in their ability to find mates. These comments stood in stark contrast to the more "desperately single" participants whom I interviewed.

\section{Courting and Capital}

Evangelicals look for numerous qualities in a potential mate. Many of these qualities are identical to those of the general population. Those in the Evangelical subculture, however, tend to find several qualities more or less attractive. To describe these

\footnotetext{
12 "Purity balls" are the "apogee" of the contemporary purity movement (Treays, 2008). These events have four essential components: the dinner, the covenant, the procession, and the dance. As the name implies, purity balls are set-up as black-tie formal affairs (somewhat akin to high school proms and wedding receptions). Fathers wear tuxedos and suits while their daughters wear gowns suitable for their high-school proms. The dinner is like any other formal dinner: a catered meal with a choice of chicken or fish. Fathers sit with their daughters, who range from four to twenty-four years of age, and listen to others, such as Randy Wilson, speak about the importance of purity (Gibbs, 2008, p. 37).

The foremost event of the evening, however, is the fathers reading and signing of the covenant. At the center of each table, there is a covenant for the fathers to sign and read aloud to their daughters. This covenant states:

I, (daughter's name)'s father, choose before God to cover my daughter as her authority and protection in the area of purity. I will be pure in my own life as a man, husband and father. I will be a man of integrity and accountability as I lead, guide and pray over my daughter and my family as the high priest in my home. This covering will be used by God to influence generations to come (Generations of Light, 2007).

Some fathers follow this reading by placing a purity ring on their daughters' ring fingers; others give their daughters locked pink boxes and the fathers "symbolically" retain the key (Valenti, 2009, p, 67). In practice, this covenant gives fathers a great deal of influence over the sexual practices of their daughters. The covenant often gives fathers the right to vet potential suitors. In other words, young men have to pass an interview with a woman's father in order to date and/or marry her (Treays, 2008).
} 


\section{Evangelical Sexual Marketplace}

qualities, I am going to reintroduce Bourdieu's concept of capital. In particular, I am going to lay out three general forms of capital that enabled my participants to attract and court potential life partners: worldly capital, Christian capital, and virgin capital.

\section{Worldly Capital}

Worldly capital includes those qualities that persons both in and outside the Evangelical sub-culture find attractive. Common items, such as physical appearance, intelligence, and compassion, fall within this category. Physical appearance was of particular importance for the male participants. Pastor Alex emphasized this fact when he half jokingly reduced what young Evangelical men look for in a mate to "big boobs." In addition, Stan and Allen both made statements to this effect. Allen actually spoke at length about a girl he once found attractive in a "worldly sense." Later, he explained what he meant by "worldly:"

Robin: You mentioned that one previous girl was attractive in a 'worldly sense.' What do you mean by that?

Allen: She defined my 'type'.... Defined my type. Just someone I would really like to get physical with mostly.

Robin: So when you use the word 'worldly' that is what you are saying?

Allen: Yes, smart and beautiful.

This section of dialogue is what led me to describe these qualities as worldly capitalelements of attraction that Evangelicals feel they share with the rest of society.

Nonetheless, the women I interviewed did not feel that physical attraction was as important when looking for a potential husband. When asked if physical appearance was important in a potential husband, Jackie, who is a single woman, responded, "No, I guess I am not really superficial. I don't know. Just as long as they don't look like a slob. You know what I mean? They actually have to make an effort to look presentable, I guess." 
Willey

In addition, when asked what qualities she would hypothetically look for in a potential mate, Alice stated: "They [sic] have to be so good looking! (laughs) No joking. For both me and [my husband] that was kind of our last, our least [important characteristic]."

These differences go a long way in explaining some of the things I observed while attending the young adults services at Grace. One (highly subjective) observation I made was the pattern of relatively good-looking girls dating relatively not-so-good-looking guys: "I am starting to see a pattern with these youth: pretty girls and nerdy guys." In comparison to men, the women at Grace appeared far less particular when it comes to physical appearance in potential husbands.

In addition to physical appearance, the participants mentioned several other more worldly items that they considered attractive. They described general qualities, such as intelligence, consideration, integrity, sense of humour, patience, and honesty, as being very important. Several participants also described having similar familial and social backgrounds as an important element in forming good relationships and marriages. Alice suggested that it was important to find a husband who understood and appreciated her "roots" and "background," and appreciated family the same way she did. Comparably, Pastor Jordan suggested that familial background was imperative in the success of one's marriage.

All but one of the participants neglected to mention that sexual compatibility would be something important for a relationship. Pastor Jordan, however, did state that a person should trust that God would not provide someone with a mate with whom one would not be sexually compatible. Conversely, Pastor Jordan did mention that knowing he/she was 'compatible' with her/his mate helped their premarital relationship. 


\section{Christian Capital}

Christian capital is a more defined Christian version of spiritual capital. All of the participants stated they would only marry a "Christian." Thus, a Christian identity became a virtual prerequisite for marriage. When I continued to inquire if denomination mattered in a potential wife/husband, all of the participants to whom I asked this probe replied that it did not. That said, many of the interviewees had rather specific definitions of what they considered the essential components of a Christian identity. Therefore, while each of the participants openly stated that denomination did not matter when meeting a mate, how they defined the essential components of the Christian faith removes individuals from certain denominations as potential mates.

Several of the participants stated that they were looking for a "mature Christian" or someone who exhibited elements of "Christian wisdom." In this regard, Stan stated:

Stan: And then also we would think of it as Christian wisdom too. Or theological wisdom.

Robin: How would you define theological wisdom?

Stan: An understanding of the Bible. Like not someone who is a beginner... 'Cause I grew up in a Christian home all of my life, right? And I see the verse in my head, 'Don't be unequally yoked.' But, yeah, that can be applied to non-Christian and Christians. But it also can be applied to two Christians at the same time. Where one person is very different in what they [sic] believe or very different in their position in their faith or whatever than another person, it's hard to, you know.

Alice referred to Christian wisdom slightly differently: "Well, I wanted, number one would be, a Christian. I would say a mature Christian . . . or a maturing Christian. Somebody who really took their [sic] Christianity to heart." Similarly, Pastor Jordan stated:

So we almost have identical backgrounds . . . and we have very identical ideas of the future and ministry and how we are in ministry and what ministry means to us. So that is very important and I can't imagine being married to somebody who 
didn't have a similar calling or similar view or similar whatever. That would be so incredibly difficult.

Thus, certain elements of faith, such as biblical knowledge and proper expression of faith, come to act as capital, which can potentially attract a mate.

Finally, Matt was the only participant to state that a belief in wifely submission was something he found important in a future mate. To this effect, he opined:

And she has to be willing to submit as I believe in the Bible it says in Genesis, I believe in chapter three, that a woman would always submit to a man. It says in the New Testament as well that a woman will always submit to a man. 'A wife should submit to her husband as husband should submit to the Lord.' . . . But the man will understand his responsibility as husband to make the wise decision and so [sic: I] he will carefully seek the council of his wife.

This was the only time I specifically heard of the doctrine of submission at Grace. For the most part, Grace appeared relatively progressive in terms of gender roles. For instance, [pseudonym suppressed] vehemently supported women in ministry and actually spoke against churches that do not allow women to hold these positions. Conversely, I found instances where women had made significant concessions for their husbands, and men certainly remained the most vocal and influential members of the church community.

\section{Virgin Capital}

From my first visit to Grace's young adult service, where the Pastor suggested that abstaining until marriage was a "universal" value held by all major religions, to my last interview where Pastor Alex affirmed the pivotal nature of abstinence in forming good marriages, I never doubted the importance of abstinence for the Evangelicals at Grace. Specifically, Pastor Alex said: 


\section{Evangelical Sexual Marketplace}

Robin: How important do you feel premarital abstinence is in forming good marriages?

Pastor Alex: I think it is really important ... I think it is probably the best gift you can give someone. You know your virginity. There is [sic] not too many things that are held sacred, and even virginity is not even held too sacred. But there will only always be one first.

Earlier he/she explained that sex was meant for marriage. Allen, however, described this concept far more clearly: “'Cause let's face it, I don't care what you believe, God set-up sex and marriage as the only way [sex] should ever happen."

Of the seven people I interviewed, six were virgins or abstained until marriage; only one, Pastor Jordan, had sex prior to marriage. Interestingly, Pastor Jordan does not consider this premarital activity to be problematic:

Like, the physical part of the relationship was good and hard. It was really good, then we felt the need to tone it down, which was really hard. We didn't wait until we were married to have sex but then as we were getting like, as we got engaged we ... just decided not to sleep together anymore, which was hard but totally worth it. So it was interesting and hard. Not like I regret sleeping with [him/her] before or anything.

That said, Pastor Jordan later admitted that many people, such as the head Pastor at his/her church, assume he/she was a virgin when she/he was married, and he/she fails to see a need to correct this assumption.

All of the interviewees said they would prefer to marry a virgin. Most said they would be willing to marry a non-virgin if that person was in a 'good' place when they met them. Allen and Stan, however, displayed more reluctance about the prospect of marriage to a non-virgin. They both argued that they deserved someone who put as much effort into remaining "pure" as they did.

The people of Grace intricately connected sexual activity and the lack thereof to one's moral character. Allen stated, "But that means, that means, you are either someone 
who did that or someone who didn't. And that shows a certain strength in character. Not your strength, God gives you the strength.” Stan suggested that abstaining was a sign that a person was "responsible" and had a degree of "maturity."

Jackie described abstinence as a key element in her Christian identity, something that separated her from the rest of the "world." Moreover, Alice connected sexual purity directly to one's spiritual worth:

Robin: So you were talking about purity earlier on, what would you consider purity? How would you sum it up?

Alice: I think it's just a respecting your body as a holy temple. I guess if we are talking about sexual purity, or more specifically bodily purity, and it is connected very much with your soul. If you respect yourself and your body and you respect it as a holy temple, especially like sexually, then it's definitely interconnected with, I guess, your soul or your spirit or Christian faith-your Christian walk. I think it's almost_-I'm pretty convinced, but not 100 percent convinced, that if you disrespect your body sexually that over time your relationship with God is strained.

According to Alice, therefore, sexual activity prior to marriage may be incompatible with faith.

The participants noted numerous other negative consequences of premarital sexual activity. Most obviously, in both the interviews and my observations at Grace, members constructed premarital sex as a risky and even dangerous activity. In other words, to have premarital sex one necessarily risked sexually transmitted infection, pregnancy, and abortion. Furthermore, Pastor Alex explained that this risk began with virtually any physical contact:

That goes back to my comment about where making-out leads to. And I have even heard some people say, making the promise that they will not do anything to their boyfriend or girlfriend that will bring on an arousal. And being a teenager, and I remember that holding hands that may happen. So where does holding hands lead? Right? The longer you can delay that initial physical contact I think the better. I think from my 
experience in seeing those things happen, I can see that [delay] being very beneficial.

Similarly, Alice, Pastor Jordan, and Stan explained that premarital sexual activity leaves a person with "baggage" and that this baggage can cause jealousy issues and/or "mistrust" in marriages. Pastor Alex described how premarital sex could result in sexual baggage in later sexual relationships; it leaves people to comparing their current partners to past partners.

Some other participants connected this concept to a sense of loss. For instance, Matt stated:

[Abstinence] has helped me because I will come to my relationship with my wife with a hope of purity, a hope of closeness. A greater relevance and depth that must be respected. It's like ... when a woman loses her virginity, you know that there is something that bleeds because it is gone; it is no more. So once you go through this door there is no coming back out again. So when I go through the door of this relationship with a woman, not even in a sexual relationship yet, I want to go to this as my first relationship with a girl. ... I I don't want to have unpleasant memories of the last girl dumping me or I have to tell her, 'you're not the one,' and then she cries.

For Matt, baggage is the "unpleasant memories" associated with failed relationships, and abstinence gives him an ability to avoid these experiences. That said, he also explains that sex causes one to lose something intrinsic to oneself.

Matt considers the hymen as a symbol of this loss. Pastor Jordan spoke of a similar sense of loss:

And I do believe that when you do sleep with somebody you do become one and you leave like a piece of you with them [sic], you know. And so. I don't think that [you] can get that back when it's gone. And when I try to talk to kids about it I think about, like, when you went to a grocery store and you wanted to buy a sandwich, you wouldn't want to buy a sandwich with a bite taken out of it, you know, with a piece missing, you know. And it kind of trivializes it a bit, but it sort of brings it into perspective. 
While I still do not quite understand what we lose when we have sex, this project is certainly not the first time I have come into contact with this notion of an incomplete self. In my previous project at Grace, I came across numerous examples of this discourse including a rather intense moment in an interview (see Willey, 2010b). ${ }^{13}$

When asked if it was more difficult for a particular gender to remain abstinent, the participants were split. Many acknowledged that men had a difficult time because of how easily they are stimulated visually. Several also stated that abstinence was easier for women because mainstream society still values female virginity. As Jackie described:

I think [it is] harder for men. 'Cause it's like more of a, like it's a status thing for guys. 'Cause they, like, it's sort of looked down on for women. They, like, call them 'sluts' maybe. Like, call them all these insults. Well for, like, guys it's almost like a compliment.... So I think it is harder for a guy.

In addition, Allen stated that "Women are-generally, it's fading, but are-generally expected to be good girls. A woman is looked on as higher if she remains abstinent until her wedding night." Thus, both Jackie and Allen acknowledge that the additional pressure placed on women to maintain their virginity (which is roughly the same pressure that feminists Valenti [2009] and Judith Levine [2002] are so critical of) can be a good thing.

Moreover, abstinence discourses pay a great deal of attention to the sexual rewards one will receive in heterosexual marriage (Wilkins, 2008, p. 143). To this effect, Pastor Alex stated, “Abstinence isn't very exciting until you get married! So that's kind of where the excitement starts." Similarly, Allen lamented those who continued to have

\footnotetext{
${ }^{13}$ In this interview, a Pastor at Grace implied that "there was a 'God-shaped vacuum' inside me there was a 'Robin-shaped' vacuum inside the church”' (Willey, 2010b).
} 
premarital sex and he struggled to understand how people do these activities in the first place:

Like, how does the world do it? How do people who are very promiscuous and just, you know, the casual sex scene, how do they do it? How can it possibly be as good? You barely know the person, the intimate connection, the intimate connection! 'Cause [sex] is the greatest expression of love between a man and a woman ... and frankly, the intimate portion of it is greater that the physical portion .... But why do people love sex so much if they are missing the biggest part of it? And that is why we have--we keep getting deeper into it.

As such, Allen firmly committed to the idea that sex is best enjoyed within the confines of marriage, and that waiting to enjoy this act until one's wedding night only increases the emotional and physical satisfaction.

Finally, I did observe some slight criticisms of premarital abstinence while conducting this project. First, Pastor Jordan did not regret the fact she/he had premarital sex and even noted some positive things came from these experiences:

Robin: Do you see any way of having sex before marriage might have helped [your relationship]?

Pastor Jordan: How would've it helped. I am not sure I haven't thought about it like that before. I think that in some ways it may have forced us to take a look at the direction the relationship was going. 'Cause it was very physical in the beginning like and ... so to have to look at it and, be, like 'what is the focus of the relationship and are we just focused on being physically satisfied or... like there is that.' It maybe brought it to light. Maybe. Maybe it didn't; maybe it would have been like if we hadn't. I don't know, that is a tough question. It is a good question.

In addition, several statements in the confessionals revealed that there are indeed Evangelicals questioning the practice of premarital abstinence. For example, one post read, “I am saving my virginity for marriage, but I'm frightened I won't be appreciated in my prime if I do.” Another post stated:

I've been going to church my whole life. Recently I've found myself more and more jaded towards Christianity. I am feeling more and more like saving myself 
for marriage, abstaining from alcohol etc. has caused me to miss out on so much that life seems to offer everyone else.

Therefore, some Evangelicals do see problems with abstinence discourses. These discourses, however, lay far outside everyday conversation.

\section{Evidence for an Evangelical Sexual Marketplace}

According to sociologist Adam Isaiah Green's "sexual fields framework," sexual marketplaces have two central components: "the spaces of sexual sociality (the site), and an attendant social structure (the field)" (Green, 2008, p. 28). In this project, the young adults group at Grace typifies the site, while the rules, hierarchies, and boundaries that young adults abide by to participate in this world composes the field.

\section{The Site}

During my time at Grace, I encountered a considerable amount of evidence that the young adults group was a site for the exchange and conversion of erotic capital-a place for young Evangelicals to meet potential life partners. Allen explained that when he finally decided to look for a girlfriend, he began by looking around church and churchrelated groups. Eventually, he met his wife at a church-related function for young adults. Later, he explained why he felt young adults groups and small groups (which are smaller Bible study groups that branch off the main young adults group) helped young Christians meet members of the opposite sex:

Allen: Yeah, just at church people feel more secure. You are around what are supposed to be good people, whether they are or not. You can let your guard down and the real you comes out a lot more. Plus there is a lot of discussion. That is what makes small groups the best place. Cause there is a lot of discussion about your heart. You can just assume that people 
are telling the truth and you can get to someone quite quickly. Those are the three biggest things I know.

Robin: Do you think that is like one of the central purposes of young adults groups?

Allen: It seems to be. Why not? There is something that happens when you get to a certain age and it becomes that.

In contrast, Jackie acknowledged that many people treated young adults groups as places

to meet but felt uncomfortable with this fact:

Robin: Now where do you think is the most likely place you will meet someone?

Jackie: Probably a coffee house. I don't know why. I think like maybe one of the youth groups I am with at my church too. [That] would also be a good bet.

Robin: So like young adults groups?

Jackie: Yup.

Robin: Do you think that is like the purpose of those groups?

Jackie: Well they often say it is. Like I know Bible colleges-- they always call them 'bridal' colleges, which is sort of funny. But I don't think that is the purpose of them. I mean. I don't know. Sometimes I get annoyed when people, like, go into those other group orientated Bible colleges to meet someone. I'm like, 'that is not really the point of it.' I actually get annoyed.

In this quote, Jackie revealed some of the discomfort Evangelicals feel about the existence of this marketplace. To this effect, Pastor Alex described that when she/he first began to pastor young adults it took some time for him/her to become comfortable seeing young people attempting to meet at her/his services. Pastor Alex also worried that if certain things went unchecked, then young adults could become like a "meat market." Arguably, young adults groups are already involved in "bar" scenes with the manifest and latent functions flipped. Bars tend to function first to connect young people in various forms of sexual relationships and second to bring people together and promote some version of community, while the church, in my view, does these things in the opposite order. 
Nonetheless, Stan, like Allen, has no problem with young adults groups performing this function. At one Bible study session, Stan joked about leaving Grace for a church with more "good-looking girls." In addition, in the interview he explained:

I have been thinking about that a lot. Because I am thinking about where can I find [a girlfriend] right? Young adults might be a possibility.... But, actually to tell you the truth I actually see young adults groups at churches equivalent to the bar scene in the secular world. 'Cause it's like, it's the place where Christians kind of go if they're interested in finding relationships.

Not only does Stan reveal the existence of a Christian sexual marketplace; but also he actually described its function in relation to a marketplace found in secular society. One participant even spoke of someone she knew who actually "church hopped," going from young adults group to young adults group, looking for a potential mate.

All of my married participants met their mates at a church, church group, or church-related activity. Moreover, while attending Grace's young adults services, I noticed that great effort was made to celebrate marriages and potential marriages. In addition, a couple I dubbed "the cuddlers" could hardly keep their hands off each other during church services. This couple typified the awkwardness that comes with the existence of this sexual marketplace. Congregants struggle to combine the "spiritual" components of the young adults service with the "fleshy" components of its associated sexual marketplace. In other words, while no one ever told the cuddlers to stop groping each other, it was often quite evident that this behavior was somewhat out of place-yet not. 
Evangelical Sexual Marketplace

\section{The Field}

One needs to follow certain rules when it comes to meeting a partner in a church. Paramount of these rules is an intricate understanding of sexual boundaries. Pastor Jordan explained that premarital couples should avoid activities that involved body parts that would normally be covered by a bathing suit. Allen described slightly stricter version of these boundaries:

To me there was always a line in between. On one side of the line is [sic] things like holding hands, rubbing backs, [and] kissing. On the other side of the line is things like groping, petting, [and] anything with your clothes off. So that's where I put the line, those things I mentioned and on either side of it.

In addition, Alice explained the difficulties she had maintaining these boundaries with her husband prior to marriage, which resulted in the implementation of a set of very strict preventative rules. Understanding the boundaries between sex and sin is an important aspect of the Evangelical sexual marketplace. The rules of sexuality define what one can and cannot do while dating. As Pastor Alex outlined there are many small things that young adults can do to help them meet potential partners, such as once a person has found someone in whom one is interested, he/she might use the groups' set-up within the church to strategically place oneself close to any particular person. That said, besides the painful negotiation of sexual boundaries, the rules of engagement for meeting a potential mate in a church are similar to those for meeting outside of one.

Pastor Alex explained that young adults groups provided him an opportunity to "encourage" certain relationships that he/she felt were "good matches." Furthermore, Pastor Alex suggested that one can really see the "parents" wisdom" in how young people select their partners. Therefore, through the influence of leaders, such as Pastor Alex, 
Willey

and the values and knowledge with which young people enter into this marketplace, the careful and subtle direction of who meets who reproduces certain hierarchies and positions. In Bordieuian terms, matching individuals who have a common habitus reproduces the values and discourses associated with that habitus.

Nonetheless, the best way to understand the structure and hierarchies embedded within this sexual marketplace is to look at for whom this market does not work. For instance, Matt spoke of the difficulties he had meeting people at church. For the most part, he attributed these difficulties to a rather demanding work schedule and that this schedule has prevented him from fully participating in a youth group for many years. Furthermore, his beliefs and values as an Evangelical Christian prevent him from participating in sexual marketplaces outside the church, which further hinders his ability to meet a mate. He also exhibited a great deal of insecurity with his intelligence, appearance, and ability to socialize. In sum, while Matt was a committed, "wise," and abstinent Christian, he lacked the worldly capital, such as wealth, appearance, and intelligence, to find a mate.

Pastor Jordan never had the opportunity to participate in this sexual marketplace. While Jordan did meet her/his partner through a church youth program, this program was outside the evangelical sexual marketplace. He/she mentioned several times how his/her identity as a Catholic/Evangelical left her/him as an outcast. Furthermore, Pastor Jordan failed to abstain until marriage. Therefore, these two points may signify that Pastor Jordan lacked the Christian and virgin capital to participate in the Evangelical sexual marketplace. First, she/he possessed theological ideas that may not have aligned with typical Evangelical belief, which affected his/her Christian capital. Second, by breaking 


\section{Evangelical Sexual Marketplace}

the rules of sexual conduct (i.e. having sex before marriage), she/he greatly altered his/her ability to convert or exchange virgin capital.

That said, a mechanism exists within evangelical Christianity that one can use to convert experiences, such as sexual misconduct, into positive capital. As mentioned earlier, a "culture of personal crisis" is embedded within Evangelical Christianity (Blumenthal, 2009). Thus, one can use this culture to convert 'sinfulness' prior to conversion or during a 'spiritual lapse' ${ }^{14}$ into spiritual/Christian capital. One person I met while in the field spoke of what he called the "bad boy effect," which essentially describes the tendency for young women to be attracted to men who have gone off and 'sewn their oats' only to see the error in their ways and begin, or return, to their 'Christian walk.' This example reveals exactly how young men (since this option is not available to women) can convert a deficiency in virgin capital into Christian capital.

\section{Implications of an Evangelical Sexual marketplace}

\section{The Demon}

In his analysis of the French education system, Bourdieu used a concept from physicist James Clerk Maxwell (1831-1879) to explain the workings of the system. Maxwell explained that in order to suspend the second law of thermodynamics one could use a "demon" to sort partials of different temperatures into separate containers. In terms of the educational system, Bourdieu stated:

The educational system acts like Maxwell's demon: at the cost of energy which is necessary for carrying out the sorting operation, it maintains the preexisting order, that is, the gap between pupils endowed with unequal amounts of cultural capital. More precisely, by a series of selection

\footnotetext{
${ }^{14}$ At a Bible study meeting, Allen spoke of "men" having "spiritual seasons" which are essentially periods of time when one feels closer or farther from God.
} 
operations, the system separates the holders of inherited cultural capital from those who lack it. Differences of aptitude being inseparable from social differences according to inherited capital, the system thus tends to maintain preexisting social differences (Bourdieu, 1998, p. 20).

Christian churches (and likely other religious communities) work in the same way.

Distracted by a guarantee of equality in the afterlife, a sort of spiritual meritocracy, Christians tend to ignore stark differences in their material lives. Evangelicals, through their efforts to be 'in' but not 'of' the world, receive a double-dose of this distraction.

Youth and young adults groups and the associated sexual marketplace play an important role for the "demon" in the church. These groups provide a space that helps guarantee the reproduction of Evangelical discourses and the social differences they produce into the next generation. In particular, young adults groups ensure that Evangelicals marry people of similar backgrounds and with similar values. Marriage, in this sense, is the Evangelical version of graduation. Bourdieu stated that in the school system "[Graduation] institutes a social difference of rank, a permanent relation of order: the elect are marked, for the whole of their lives, by their affiliation" (Bourdieu, 1998, p. 21). Marriage marks the point in which the Evangelical couple guarantees the continuation of difference. It marks the passage into adulthood—passage into social legitimacy.

\section{The Reproduction of Age}

In an Evangelical church, through marriage and the vicarious passage into adulthood, the community expects individuals to leave behind the problems and questions 


\section{Evangelical Sexual Marketplace}

associated with young adulthood. ${ }^{15}$ As a result, they are able to move into forums within the church (and elsewhere) where their opinions carry far more legitimacy. ${ }^{16}$ As Stan noted with a degree of frustration, "And I find that right after young adults, right after they get engaged and married or something, they just leave [the young adults group]. Cause they found [what they came for]. Why come to young adults anymore?"

Therefore, Evangelical youth and young adults rely on youth leaders, such as Pastor Alex and Pastor Jordan, to advocate for them. For example, Pastor Jordan was quite critical of the existence of youth and young adults groups and strongly advocated for an increase in mentorship within churches, thus building more connections between youth and adults rather than boundaries.

Nonetheless, many church leaders are often far more inclined to subscribe to the very essentialist notions of youth that delegitimize young people in the first place. For instance, during my time at Grace one specific sermon focused on how youth lacked knowledge, and how they should learn to listen to their elders. The Pastor problematized the fact that youth turn to their peers for "wisdom" and continued to describe youth as prone to destructive behavior, such as drinking, sex, and/or having part-time jobs. In fact, during this service an individual actually suggested that young people have a "pride" problem and need to "surrender their rights" in order to hear wisdom. In another instance, an adult member of Grace cried out for church members to pray for deviant youth who have turned away from the church. Situations such as these are excellent examples of symbolic violence and the perpetuation of social difference. Church

\footnotetext{
${ }^{15}$ Allen, a married male, stated that often he was frustrated with the questions asked by young adults while he was a member of Grace's young adults group and believed that as a mature Christian one should eventually learn not to question things.

${ }^{16}$ While I do know that married males occupy virtually every important position at Grace, I am unaware if marriage is an official requirement for these positions.
} 
Willey

discourses continually construct young people as morally and socially deficient in comparison with their adult peers, even though at times the only real difference is a marital contract.

That said, part of what Grace's young adults group does, and secular society fails to do, is provide a space where young people can speak safely about issues important to them (even if this space leaves them as an Evangelical under-class). The group allows individuals to toy with certain theological ideas without fear of repercussion and meet in a place that does not require the ingestion of "mind altering substances" as a rite of passage. That said, it is assumed that one will settle eventually on orthodoxy and follow the general beliefs of the church.

\section{The Reproduction of Gender}

Not surprisingly, since abstinence and its related discourses have tended to favor men historically, so does the sexual marketplace that deems abstinence valuable. Evangelical sociologist, Mark Regnerus, noted that one of the greatest problems facing Evangelical churches is the lack of Christian men. Furthermore, Regnerus argued that young men are taking advantage of this situation (Regnerus, 2009). Couple this situation with Evangelical women's fear of not meeting a man (as revealed by Alice and numerous web confessions), and Evangelical men are left in an advantageous position. Stan and Allen are excellent examples of this phenomenon. Both firmly committed to the fact that God would indeed provide them with an ideal mate and, more importantly, that they deserve this 'gift.' In addition, Pastor Alex supported a father's ability to vet potential suitors. 
Evangelical Sexual Marketplace

Furthermore, as Wilkins suggested, Evangelical marriage often solidifies conservative gender roles and ends the leeway many women experience prior to marriage (Wilkins, 2008, p. 149). For instance, while all of the women whom I interviewed had attained a university degree, one of these women quit her academic ambitions as soon as she was married. In time, it became quite apparent that her own desires came second to those of her husband. Furthermore, her husband did not make any similar concessions and even said that finding a wife who would not inhibit his own ambitions and goals was important to him. Thus, while abstinence does allow women some reprieve from the mainstream sexual marketplace, this relief is undone by the reintroduction of conservative gender roles in marriage.

\section{Conclusion}

The combination of Green's “sexual fields framework," Bourdieu's work on religion, and ethnographic analysis becomes a powerful tool for analyzing the sexual politics and practices of a specific group of people in a specific place. In my time at Grace, I encountered a large amount of evidence to suggest that a defined sexual marketplace existed within the church, and that this marketplace was instrumental in the reproduction of discourses related to sexuality, age, and gender. While young adults groups are not quite bar scenes, they are certainly close to being bar scenes in some respects. These groups provide a "safe" place for young Christians to meet potential mates, a place where they are more likely to find a mate who will not challenge elements of a person's habitus in any fundamental way. As such, young adults groups function to reproduce a common Evangelical habitus while maintaining all of the internal differences 
and hierarchies that exist within the church. In other words, material differences are spiritualized in such a way in the church that they are no longer recognized as such.

As I implied earlier, Evangelicals have far more in common with the rest of society, in how they understand relationships and what they find attractive, than they have differences. In terms of this project, Evangelicals and mainstream society share a general understanding of monogamy and look for similar qualities in a life partner, such as a pleasant appearance, intelligence, honesty, and general interpersonal compatibility. I have focused, however, on those few but very important differences.

The Evangelicals in my study intricately connected the process of finding a mate and dating to one's spirituality. In other words, the hope is that one can become attracted to a person through a person's 'spirit' and 'personhood,' rather than through the 'flesh' and 'lust,' This stark 'spirit/flesh' dichotomy was a common motif at Grace. ${ }^{17}$ While this practice intends to help individual Christians see past the superficial qualities in a potential mate, in reality it creates a perfect opportunity for outside social forces to influence how young adults select mates and whom they select. It causes these agents to "misrecognize" the material forces that are systematically limiting who they can potentially meet. In other words, an Evangelical's use of 'God' in finding a mate provides an ideal opportunity for "symbolic violence." It provides an opportunity for others in more powerful positions to "gently," "imperceptibly," and "invisibly" alter what young people see as desirable in a mate vicariously altering their sexual habitus (Bourdieu, 2001, p. 1).

\footnotetext{
${ }^{17}$ Evangelicals often refer to this dichotomy in several other ways as well, such as 'Godly' and 'worldly' or 'secular' and 'Christian. All of these examples, however, connote the same difference between what Evangelicals consider the design of God defined by the Bible, and those strategies and items of human design. One of my participants actually separated virginity into two elements - "spiritual" and "physical."
} 
Evangelical Sexual Marketplace

\section{References}

Abbott, Elizabeth. (1999). A History of Celibacy. Toronto: HarperCollins.

Bartkowski, John P. (2001). Remaking the Godly Marriage: Gender Negotiation in Evangelical Families. New Brunswick, NJ: Rutgers University Press.

Bloor, Micheal, \& Wood, Fiona. (2006). Key Words in Qualitative Methods. London: Sage.

Blumenthal, Max. (2009, Nov. 16). The Palin Effect. The Nation. Retrieved from http://www.thenation.com/doc/20091130/blumenthal on Nov. 20, 2009.

Bourdieu, Pierre (1977). Outline of a Theory of Practice. Cambridge: Cambridge University Press.

(1986). The Forms of Capital. In Richardson, John G. (ed.), Handbook of Theory and Research for the Sociology of Education. New York, NY: Greenwood. Retrieved from http://www.marxists.org/reference/subject/philosophy/works/fr/bourdieu-formscapital.htm on Mar. 14, 2010.

(1987). Legitimation and Structured Interests in Weber's Sociology of Religion. In Lash, Scott, \& Whimster, Sam. (eds.), Max Weber, Rationality and Modernity (pp. 119-136). London: Allen \& Unwin.

----- (1991). Genesis and Structure of the Religious Field. Comparative Social Research. $13,1-44$.

------ (1996). On Television. New York: The New Press.

----- (1998). Practical Reason. Stanford, CA: Stanford University Press.

----- (2001). Masculine Domination. Palo Alto, CA: Stanford University Press.

Bourdieu, Pierre \& Loïc Wacquant (1992). An Invitation to Reflexive Sociology. Chicago: University of Chicago Press.

Conkin, Paul K. (1997). American Originals: Homemade Varieties of Christianity. London: University of North Carolina Press.

Engler, Steven. (2003). Modern Times: Religion, Consecration and the State in Bourdieu. Cultural Studies. 17, 445-467.

Fowler, Robert, Hertzke, Allen, Olson, Laura, \& Den Dulk, Kevin. (2004). Religion and Politics in America. Boulder, CO: Westview Press. 
Willey

Gallagher, Sally K. (2003) Evangelical Identity and Gendered Family Life. New Brunswick, NJ: Rutgers University Press.

Gallagher, Sally K.; Wood, Sabrina L. (2005). Godly Manhood Going Wild?: Transformations in Conservative Protestant Masculinity. Sociology of Religion, 66 (2), 135-159.

Generations of Light. (2007). “The Pledge.” Retrieved from http://www.generationsoflight.com/generationsoflight/html/ThePledge.html on Apr. 7, 2009.

Gibbs, Nacy. (2008, July 28). The Pursuit of Purity. Time (Canadian Ed.), 36-39.

Green, Adam Isaiah. (2008). The Social Organization of Desire: The Sexual Fields Approach. Sociological Theory, 26(1), 25-50.

Levine, Judith. (2002). No-Sex Education: From 'Chastity' to 'Abstinence'. In Kimmel, Michael, \& Plante, Rebecca. (eds.), (2004). Sexualities: Identities, Behavior, and Society (pp. 438-455). New York Oxford: Oxford University Press.

Martin, John Levi, \& George, Matt. (2006). Theories of Sexual Stratification: Toward an Analytics of the Sexual Field and a Theory of Sexual Capital. Sociological Theory, 24(2), 107- 132.

Putnam, Robert D. (2000). Bowling Alone: The Collapse and Revival of American Community. New York, NY: Simon \& Schuster.

Pengelly, Brian. (2010). Putting the Pieces Together: Making a Me that Really Fits. New Direction Ministries of Canada. Retrieved from http://www.newdirection.ca/content.xjp?id=230 on Jul. 9, 2010.

Pevey, Carolyn; Williams, Christine L.; Ellison, Christopher G. (1999). Male God Imagery and Female Submission: Lessons from a Southern Baptist Ladies' Bible Class. Qualitative Sociology, 19(2), 173-193.

Regnerus, Mark. (2009). The Case for Early Marriage. Christianity Today. Retrieved from http://www.christianitytoday.com/ct/2009/august/16.22.html on Apr. 8, 2010.

Reimer, Sam. (2003). Evangelicals and the Continental Divide: The Conservative Protestant Subculture in Canada and the United States. Montreal: McGill-Queens University Press.

Rey, Terry. (2004). Marketing the Goods of Salvation: Bourdieu on Religion. Religion, $34,331-343$. 
Evangelical Sexual Marketplace

----- (2007). Bourdieu on Religion: Imposing Faith on Legitimacy. London: Equinox.

Snow, David A., \& Machalek, Richard. (1984). The Sociology of Conversion. Annual Review of Sociology, 10, 167-190.

Treays, Jane. (2008, September 21). A Virgin Army Proclaiming the Thrill of the Chaste. The Sunday Times. Retrieved from http://women.timesonline.co.uk/tol/life_and_style/women/relationships/article479 3419.ece on Feb. 4, 2009.

Valenti, Jessica. (2009). The Purity Myth: How America's Obsession with Virginity Is Hurting Young Women. Berkley, CA: Seal Press.

Verter, Bradford (2003). Spiritual Capital: Theorizing Religion with Bourdieu against Bourdieu. Sociological Theory. 21, 150-174.

Wacquant, Loïc. (2004). Body and Soul: Notebooks of an Apprentice Boxer. Oxford: Oxford University Press.

Willey, Robin D. (2010a). Discovering the Evangelical Sexual Marketplace: An Ethnographic Analysis of the Development, Exchange, and Conversion of Erotic Capital in an Evangelical Church (Master's thesis). University of Alberta, Edmonton, AB.

------ (2010b). Becoming Data: Star Trek Wisdom and the Effects of Fieldwork on the Fieldworker. Journal of Religion and Popular Culture, 22(3). Retrieved from http://www.usask.ca/relst/jrpc/art22\%283\%29-data.html on Jan. 30, 2010.

Wilkins, Amy C. (2008). Wannabees, Goths, and Christians: The Boundaries of Sex Style and Status. Chicago, IL: University of Chicago Press.

Wuthnow, Robert. (2000). How Religious Groups Promote Forgiving: A National Study. Journal for the Scientific Study of Religion, 39, 125-139. 